\title{
Pengembangan Media Uploading untuk Mendukung E-Learning pada Kondisi Jaringan Dinamis
}

\author{
Rahmat Daniyanto, Waskito Wibisono, dan Royyana Muslim Ijtihadie \\ Departemen Teknik Informatika, Fakultas Teknologi Informasi, Institut Teknologi Sepuluh Nopember (ITS) \\ e-mail: hari@its-sby.edu
}

\begin{abstract}
Abstrak-Kemajuan teknologi informasi saat ini memudahkan setiap orang dalam kegiatannya masing-masing, Saat ini kegiatan belajar mengajar tidak harus dilakukan dengan cara tatap muka langsung tetapi dapat dilakukan dengan melalui secara online melalui internet. Pengajar dan murid dapat berkomunikasi melalui suatu web yang didesain untuk memudahkan kegiatan belajar mengajar.Saat ini masyarakat dapat mengakses internet melalui media seperti komputer, laptop serta smartphone yang sudah banyak digunakan. Pada web terdapat banyak fungsi yang dapat digunakan oleh pengguna untuk berdiskusi antar pengajar dan murid . Salah satunya pengajar dapat memberikan tugas pada murid. Pengajar dapat membuat topik bahasan tertentu lalu murid mengumpulkan tugas yang dikerjakan dengan cara mengunggahnya. Namun kualitas koneksi internet tidak selalu baik, ada kalanya koneksi internet yang buruk mengakibatkan proses mengunggah tugas menjadi gagal. Hasil makalah ini, elearning akan digunakan sebagai sarana pengumpulan tugas. Dalam proses mengunggah, web akan menggunakan Chunked Upload Progress yang memungkinkan pengguna untuk mengatasi masalah koneksi yang buruk saat mengupload Upload Progress akan tersimpan saat proses mengunggah sedang berlangsung pada kondisi koneksi jaringan yang dinamis.
\end{abstract}

Kata Kunci-Adaptif, jaringan dinamis, e-learning, Chunked Upload Progress.

\section{PENDAHULUAN}

$\mathrm{K}$ EGIATAN belajar mengajar secara online yaitu $e$ learning telah dilakukan beberapa perguruan tinggi di Indonesia. Dengan e-learning tersebut pengajar dan murid dapat berinteraksi secara langsung. E-learning memudahkan pengajar dan murid untuk bertatap muka dengan tidak perlu bertemu untuk kegiatan belajar mengajar, tetapi hanya cukup menggunakan media seperti smartphone atau komputer.

Tantangan yang ada sekarang ini yaitu bagaimana mengatur kualitas pengiriman multimedia tersebut sesuai dengan kondisi traffic jaringan internet. Seperti yang diketahui, kondisi jaringan internet tidak selalu lancar. Banyak sekali hambatan yang menyebabkan kondisi jaringan tidak stabil. Untuk komunikasi real time membutuhkan pengaturan terhadap multimedia sesuai dengan kondisi jaringan agar mengantisipasi adanya delay yang terlalu lama sehingga mengurangi kualitas dari layanan komunikasi tersebut.

Kondisi jaringan dinamis adalah keadaan suatu koneksi jaringan yang berubah-ubah sesuai dengan kondisi traffic jaringan. Keadaan yang berubah-ubah tersebut yang menyebabkan pengiriman paket pada jaringan memerlukan waktu yang berbeda-beda.Semakin baik kondisi traffic jaringan, maka semakin baik pula pengiriman yang dilakukan. Sebaliknya jika kondisi traffic jaringan jelek, maka semakin lambat pula pengiriman yang dilakukan.

Dalam makalah ini, plugin pada Content Management System (CMS) [1] elearning akan digunakan sebagai sarana pengumpulan tugas.. Dalam proses mengunggah, web akan menggunakan Chunked Upload Progress [2] yang memungkinkan pengguna untuk mengatasi masalah koneksi yang buruk saat mengupload Upload Progress akan tersimpan saat proses mengunggah sedang berlangsung pada kondisi koneksi jaringan yang dinamis.

\section{TINJAUAN PUSTAKA}

\section{A. Pembelajaran Kolaboratif}

Pembelajaran kolaboratif [2] merupakan sebuah metode pembelajaran dimana para murid yang memiliki kemampuan yang berbeda-beda satu sama lain dikumpulkan dalam kelompok kecil untuk menyelesaikan satu permasalahan yang sama.

Dalam pembelajaran kolaboratif, setiap murid akan menjadi pusat baik dalam aktivitas mengajar maupun belajar, dan proses belajar merupakan sebuah proses dimana mereka memahami tentang konsep dan fakta kemampuan dari mereka sendiri [3]. Di dalam pembelajaran ini, mereka akan menjadi pelajar yang aktif karena mereka membentuk pengetahuan dengan cara melakukan interaksi sosial dengan murid lain yang memiliki pengetahuan lebih.

Tabel 1

Model Pembelajaran Kolaboratif [3]

\begin{tabular}{|c|c|c|}
\hline & Waktu sama & Waktu berbeda \\
\hline Tempat Sama & \begin{tabular}{l}
\multicolumn{2}{c}{ (a) } \\
Pembelajaran dengan \\
bertemu langsung \\
dalam satu ruangan \\
kelas
\end{tabular} & \begin{tabular}{lr}
\multicolumn{2}{c}{ (b) } \\
Pembelajaran \\
dengan berdiskusi \\
di dalam & satu \\
ruangan & kelas \\
namun & dalam \\
waktu & yang \\
berbeda &
\end{tabular} \\
\hline Tempat berbeda & \begin{tabular}{lr}
\multicolumn{2}{c}{ C } \\
Pembelajaran dalam \\
waktu yang \\
bersamaan namun \\
berada pada jarak jauh \\
menggunakan internet
\end{tabular} & \begin{tabular}{l}
\multicolumn{2}{c}{$(\mathrm{d})$} \\
Pembelajaran \\
menggunakan \\
internet namun \\
tidak dalam waktu \\
yang $\quad$ sama,
\end{tabular} \\
\hline
\end{tabular}




\begin{tabular}{lll}
\hline \hline atau & teknologi & misalkan \\
informasi & & $\begin{array}{l}\text { menggunakan } \\
\text { email, video, atau } \\
\text { buletin }\end{array}$ \\
& \\
\hline
\end{tabular}

Melihat pada Tabel 1, ada empat model pembelajaran kolaboratif yang umumnya ada berdasarkan cara komunikasi antara para pelajar yang dibagi berdasarkan variabel waktu dan tempat. Empat model pembelajaran kolaboratif tersebut dapat dijelaskan sebagai berikut [3].

(a) Waktu sama - Tempat sama

Model ini merupakan model pembelajaran kolaboratif yang paling umum dilakukan, dimana setiap anggota dalam suatu kelompok saling berinteraksi dan berdiskusi satu sama lain dalam waktu dan tempat yang sama, biasanya dalam bentuk pertemuanuntuk berdiskusi masalah tertentu.

(b) Waktu berbeda - Tempat sama

Model kolaborasi ini biasanya dilakukan dengan memberikan informasi tentang pertanyaan atau informasi lainnya ke kelompok dengan menggunakan buletin atau papan tulis.

(c) Waktu sama - Tempat berbeda

Model ini biasanya membutuhkan adanya komunikasi dalam waktu yang sama (Real Time) dalam lingkungan yang berbeda. Alat-alat yang digunakan biasanya meliputi fitur panggilan video, audio, dan media lainnya yang mendukung kemampuan berbagi informasi dan berdiskusi dalam kelompok secara real time.

(d) Waktu berbeda - Tempat berbeda

Model ini pada saat ini adalah yang merupakan paling banyak digunakan karena membutuhkan terjadinya komunikasi dalam waktu yang berbeda dan tempat yang berbeda pula. Alat-alat yang digunakan biasanya berupa surat elektronik, forum, blog, dan lainnya untuk berbagi informasi dan berdiskusi dalam kelompok pelajar.

\section{B. Kondisi Jaringan Dinamis}

Kondisi jaringan dinamis adalah keadaan suatu koneksi jaringan yang berubah-ubah sesuai dengan kondisi traffic jaringan. Keadaan yang berubah-ubah tersebut yang menyebabkan pengiriman paket pada jaringan memerlukan waktu yang berbeda-beda. Kondisi tersebut juga dapat mempengaruhi komunikasi multimedia pada jaringan. Untuk mengantisipasi adanya delay yang terlalu lama antar paket yang dikirimkan, diperlukan adanya mekanisme untuk mengatur pengiriman paket multimedia. Mekanisme tersebut bisa diterapkan dengan mengukur kinerja jaringan untuk mendapatkan jitter, packet-loss, dll. Nilai dari pengukuran tersebut kemudian dijadikan acuan untuk mengatur konstrain video dan audio yang akan dikirim.

\section{C. $P H P$}

PHP [4] merupakan bahasa pemrograman script server-side yang didesain untuk pengembangan web. Selain itu, PHP juga bisa digunakan sebagai bahasa pemrograman umum. PHP disebut bahasa pemrograman server-side karena PHP diproses pada komputer server. Hal ini berbeda dibandingkan dengan bahasa pemrograman client-side seperti JavaScript yang diproses pada web browser (client).

Kode PHP dapat dicampur dengan kode HTML, atau dapat digunakan dalam kombinasi dengan berbagai mesin template dan kerangka web. Kode PHP biasanya diproses oleh interpreter PHP, yang biasanya diimplementasikan sebagai modul asli web server atau Common Gateway Interface (CGI) executable. Setelah kode PHP ditafsirkan dan dilaksanakan, server web mengirimkan output yang dihasilkan ke klien, biasanya dalam bentuk bagian dari halaman web yang dihasilkan; misalnya, kode PHP dapat menghasilkan halaman Web kode HTML, gambar, atau data lainnya. PHP juga telah berkembang untuk menyertakan Command Line Interface (CLI) dan dapat digunakan dalam aplikasi grafis.

\section{Asynchronous JavaScript and XML (AJAX)}

AJAX [5] merupakan salah satu teknik pengembangan website yang memungkinkan halaman situs dapat menerima konten secara dinamis melalui server. Pertukaran data antara pengguna dengan server dilakukan secara asinkron, sehingga tidak mengganggu tampilan situs. Implementasi AJAX sendiri memanfaatkan gabungan beberapa komponen, yaitu:

- Situs dengan halaman XHTML dan CSS.

- Tampilan dinamis dan interaktif dengan memanfaatkan Document Object Model (DOM).

- Pertukaran dan manipulasi data menggunakan XML dan XSLT.

- Menerima data secara asinkron menggunakan XMLHttpRequest

- JavaScript untuk menggabungkan seluruh komponen tersebut.

Perbandingan antara aplikasi web klasik dengan aplikasi web dengan menggunakan AJAX. Aplikasi web tanpa AJAX melakukan permintaan ke web server kemudian memberikan respon dalam bentuk halaman HTML, sehingga pengguna akan mengalami perpindahan halaman. Berbeda jika situs mengimplementasi AJAX, permintaan ke web server dilakukan melalui perantara JavaScript dengan memanggil objek XMLHttpRequest. Web server akan mengirimkan respon berupa data XML yang kemudian diolah untuk ditampilkan ke dalam bentuk HTML dan CSS.

Meskipun objek yang digunakan adalah XMLHttpRequest, namun pada perkembangannya respon yang diolah tidak selalu berupa XML. Saat ini, jenis respon yang populer digunakan adalah dalam format JSON (JavaScript Object Notation) yang umumnya digunakan bersamaan dengan jQuery. Selain dalam bentuk teks yang telah terformat, respon juga dapat berupa plain text yang dibuat dalam format sesuai keinginan programmer.

\section{ANALISIS DAN PERANCANGAN}

\section{A. Deskripsi Umum Sistem}

Kegiatan belajar mengajar secara online yaitu e-learning telah dilakukan beberapa perguruan tinggi di Indonesia. Dengan e-learning tersebut pengajar dan murid dapat berinteraksi secara langsung.Pada penelitian ini dibangun sebuah plugin pada sebuah CMS untuk e-learning yang memiliki kemampuan untuk mengunggah tugas yang 
dkerjakan murid yang adaptif terhadap keadaan jaringan saat proses mengunggah dilakukan.Hasil akhir aplikasi web ini dapat beradaptasi dengan keadaan jaringan normal,lambat maupun terputusny koneksi saat murid melakukan proses pengumpulan tugas

Proses kerja modul ini bermula dengan pengecekan kecepatan upload jaringan pengguna, yang nantinya akan berpengaruh dalam proses pengiriman file.koneksi jaringan terbagi menjadi baik dan buruk. Apabila koneksi baik maka proses pengiriman file akan dilakukan dengan keadaan normal sedangkan apabila keadaan jaringan buruk ukuran chunked file akan diubah menyesuakan dengan kecepatan upload pengguna.

Apabila dalam proses pengiriman file terjadi gangguan koneksi yang menyebabkan terputusny koneksi dengan server ,maka pengguna dapat melanjutkan proses pengiriman file tersebut dengan syarat nama file dan ukuran file yang dikirim sama dengan file yang dikirim sebelumnya.

\section{B. Arsitektur Umum Sistem}

Agar dapat menjalankan fungsinya, maka alur kerja dari kesatuan aplikasi ini dirancang seperti pada Gambar 1.

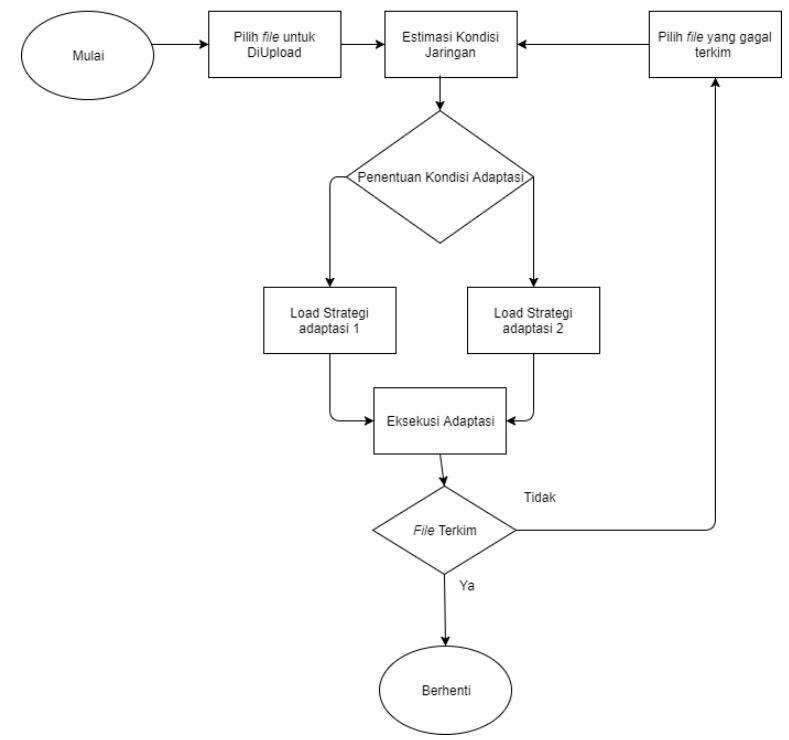

Gambar 1. Gambaran Umum Alur Kerja Aplikasi

Berdasarkan Gambar 1, alur kerja aplikasi ini dijabarkan sebagai berikut:

1. Klien melakukan inisialisasi koneksi peer dengan mengirimkan identitas yang telah didaftarkan sebelumnya kepada server. Server akan mengecek identitas dari klien pada database

2. Ketika klien ingin mengunggah file ke aplikasi ,klien terlbih dahulu memilih letak file yang akan dikirim.

3. Lalu aplikasi mengecek kondisi Jaringan, apabila kondisi jaringan sedang buruk maka akan masuk strategi adaptasi 1 sedangkan apabila kondisi jaringan baik akan masuk strategi adaptasi 2 .

4. Strategi adapatasi 1 terjadi saat jaringan buruk. File yang akan dikirim akan disimpan sementara pada folder pada device klien. Proses pengunggahan akan diulang saat koneksi jaringan telah baik
5. Strategi adaptasi 2 terjadi saat kondisi jaringan baik. File akan langsung diunggah ke Web

6. Apabila saat proses jaringan terputus maka klien dapat melanjutkan proses mengirimkan file dengan mengirim file dengan nama dan ukuran yang sama ,apabila file berhasil terkirim maka proses akan berhenti

\section{Perancangan Umum Sistem}

Diagram konteks merupakan diagram alir yang menggambarkan sistem secara umum. Semua aktor eksternal serta aliran data masuk dan keluar sistem digambarkan dalam satu diagram, dimana keseluruhan sistem digambarkan dalam satu proses. Konteks diagram aplikasi ini ditunjukkan pada Gambar 2.

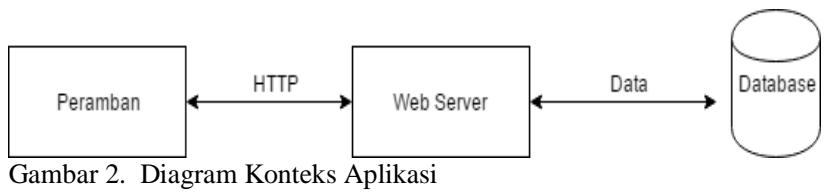

Seperti yang ditunjukkan pada Gambar 2, sistem ini akan menerima HTTP request dari peramban untuk membuka aplikasi. Web server mengirim konten yang diminta oleh peramban.. lalu data disimpan kedalam database.

\section{IMPLEMENTASI}

Implementasi dilakukan dengan menambahkan dua tabel tambahan pada CMS yang ada yaitu tabel kelas_tugas_pengumpulan untuk menyimpan informasi file yang dimiliki klien dan tabel kelas_tugas_pengumpulan_chunk untuk menyimpan informasi dari potongan file yang disimpan saat proses pengunggahan .

Pada awalnya server akan mengecek kecepatan unggah yang dimiliki oleh murid. Proses pengecekan dimulai dari server memberi perintah kepada peramban murid untuk mengirimkan sebuah data .Lalu saat server menerima data tersebut, server menghitung waktu jeda pengiriman data .Dengan proses tersebut didapatkan informasi kecepatan unggah yang akan digunakan untuk skema adapatif.

File yang dikirimkan menggunakan Json , dikirimkan per bagian . Variabel yang dikirimkan yaitu urutan,total ,token,chunksize dan Filesize. Apabila file telah terkirim semua file akan di gabungkan kembali.

Apabila jaringan terputus,saat proses pengiriman file oleh pengguna ,maka pengguna dapat melanjutkan proses pengiriman file. Pengguna dapat melanjutkan proses pengiriman dengan cara mengirimkan file yang sama(dengan syarat nama dan ukuran sama seperti file yang gagal terkirim.

\section{PENGUJIAN DAN EVALUASI}

Pengujian fungsionalitas dilakukan dengan menyiapkan sejumlah skenario sebagai tolok ukur keberhasilan pengujian. Pengujian fungsionalitas dengan mengacu pada kasus penggunaan dari aplikasi yang dikembangkan. Hasil pengujian fungsionalitas menunjukkan semua skenario pengujian berhasil dan program berjalan dengan baik. Sehingga bisa disimpulkan bahwa fungsionalitas dari program telah bisa 
bekerja sesuai dengan yang diharapkan. Hasil pengujian fungsionalitas dapat dilihat pada Tabel 1. Gambar 7 sampai Gambar 17 menunjukkan tampilan hasil uji coba fungsionalitas.

Tabel 2.

Rekapitulasi hasil uji coba fungsionalitas

\begin{tabular}{|c|c|c|c|}
\hline ID & Deskripsi & & Hasil \\
\hline UJ-UC-001 & $\begin{array}{l}\text { Uji Coba } \text { Mengecek } \\
\text { Kecepatan }\end{array}$ & Skenario 1 & Berhasil \\
\hline UJ-UC-002 & $\begin{array}{l}\text { Uji Coba Mengirim file } \\
\text { Tugas }\end{array}$ & Skenario 1 & Berhasil \\
\hline UJ-UC-003 & $\begin{array}{l}\text { Uji Coba Mengirim Tugas } \\
\text { Melalui Kamera }\end{array}$ & Skenario 1 & Berhasil \\
\hline UJ-UC-004 & $\begin{array}{l}\text { Uji Coba Melanjutkan } \\
\text { Pengiriman Tugas }\end{array}$ & Skenario 1 & Berhasil \\
\hline
\end{tabular}

\section{start: 1495593304084 \\ end : 1495593315019 \\ durasi: 10.935 \\ size: 1048576 \\ Speed Result: 93.64 /Kbps \\ Speed Result: 0.09 /Mbps}

Gambar 3. Uji Coba Mengecek Kecepatan

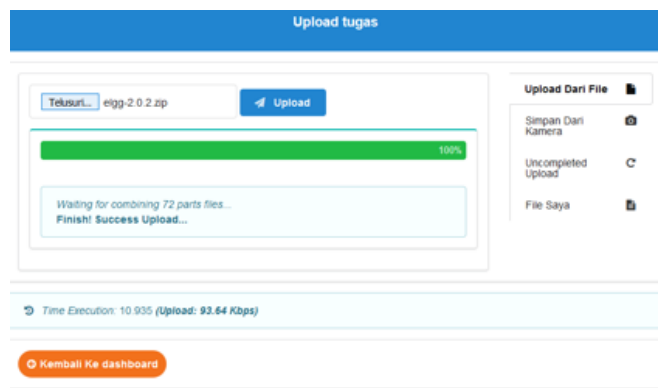

Gambar 4. Uji Coba Mengirim file Tugas

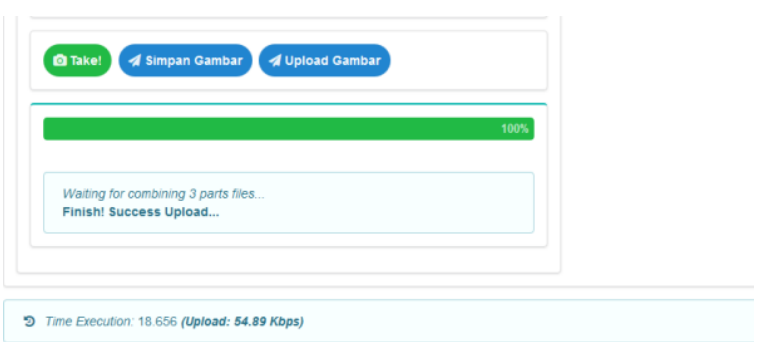

Gambar 5. Uji Coba Mengirim Tugas melalui Kamera

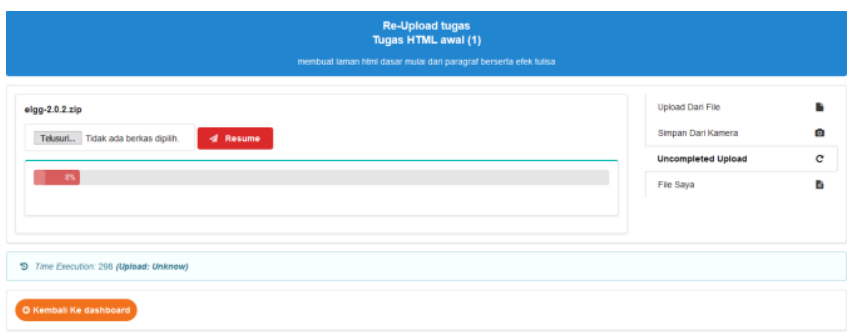

Gambar 6. Uji Coba Melanjutkan Pengiriman Tugas

Uji coba performa untuk mengetahui perilaku dari sistem ketika dijalankan pada keadaan sebenarnya. Uji coba ini dilakukan menggunakan skenario perubahan kondisi jaringan dengan cara menggunakan fitur penyesuaian kondisi jaringan yang terdapat pada Google Chrome. Penyesuaian kondisi jaringan pada Google Chrome memungkinkan menguji situs pada berbagai koneksi jaringan, termasuk Edge, 3G, dan bahkan offline. Ini juga membatasi throughput pengunduhan dan pengunggahan maksimum. Manipulasi latensi memaksa penundaan minimum pada round-trip time (RTT) koneksi.Pada uji coba ini akan dilakukan beberapa pengiriman file yang sama berukuran $1 \mathrm{MB}$ dalam keadaaan kondisi jaringan yang berbeda.

Tabel 3

Kecepatan Upload pada saat Uji Coba

\begin{tabular}{lll}
\hline \hline No & Keadaan jaringan & $\begin{array}{l}\text { Kecepatan } \\
\text { upload(Kbps) }\end{array}$ \\
\hline 1 & Normal & 55.18 \\
2 & Regular 3g & 23.29 \\
3 & GPRS & 2.44 \\
\hline \hline
\end{tabular}

Tabel 4.

Hasil Uji Coba Performa dalam keadaan normal

\begin{tabular}{llll}
\hline \hline No & $\begin{array}{l}\text { Waktu Pengiriman } \\
\text { Server } \\
\text { (Jam:menit:detik) }\end{array}$ & $\begin{array}{l}\text { Waktu Penerimaan } \\
\text { Server } \\
\text { (Jam:menit:detik) }\end{array}$ & $\begin{array}{l}\text { Waktu } \\
\text { Selisih(d } \\
\text { etik) }\end{array}$ \\
\hline 1 & $20: 15: 30$ & $20: 16: 03$ & 33 \\
2 & $20: 16: 46$ & $20: 17: 08$ & 22 \\
3 & $20: 18: 17$ & $20: 18: 48$ & 31 \\
4 & $20: 20: 04$ & $20: 20: 35$ & 31 \\
5 & $20: 21: 22$ & $20: 21: 56$ & 34 \\
6 & $20: 22: 38$ & $20: 23: 12$ & 34 \\
7 & $20: 24: 05$ & $20: 24: 26$ & 21 \\
8 & $20: 25: 09$ & $20: 25: 39$ & 30 \\
9 & $20: 26: 16$ & $20: 26: 42$ & 26 \\
10 & $20: 28: 03$ & $20: 28: 32$ & 29 \\
Rata- & & & $=29.1$ \\
rata & & & \\
\hline \hline
\end{tabular}

Tabel 5.

Hasil Uji Coba Performa pada Keadaan Regular 3G

\begin{tabular}{llll}
\hline \hline No & $\begin{array}{l}\text { Waktu Pengiriman } \\
\text { Server } \\
\text { (Jam:menit:detik) }\end{array}$ & $\begin{array}{l}\text { Waktu } \\
\text { Server (Jam:menit:detik) }\end{array}$ & $\begin{array}{l}\text { Penerimaan } \\
\text { Waktu } \\
\text { Selisih(deti }\end{array}$ \\
\hline 1 & $20: 39: 42$ & $20: 40: 42$ & 60 \\
2 & $20: 42: 04$ & $20: 42: 55$ & 51 \\
3 & $20: 43: 12$ & $20: 43: 58$ & 46 \\
4 & $20: 45: 44$ & $20: 46: 33$ & 49 \\
5 & $20: 48: 14$ & $20: 49: 01$ & 47 \\
6 & $20: 49: 25$ & $20: 50: 14$ & 48 \\
7 & $20: 50: 28$ & $20: 52: 17$ & 109 \\
8 & $20: 52: 34$ & $20: 53: 31$ & 57 \\
9 & $20: 53: 45$ & $20: 55: 32$ & 107 \\
10 & $21: 05: 49$ & $21: 07: 43$ & 114 \\
Rata-rata & & & $=68.8$ \\
\hline \hline
\end{tabular}

Uji Setelah itu dilakukan juga uji coba performa yang membandingkan proses metode pengunggahan yang terdapat pada studi ini yaitu dengan cara memotong-motong file yang dikirim terlebih dahulu dengan metode pengiriman file normal yang dilakukan tanpa melakukan proses pemotongan file terlebih dahulu.Setelah diadakan uji coba tersebut hasilnya metode pengiriman file menggunakan metode pemotongan file rata rata memiliki proses lebih lama yaitu 32 detik sedangkan apabila tanpa proses pemotongan file dapat dikirim ke server dalam waktu rata-rata 21 detik.Proses pengiriman file menggunakan metode pemotongan file memakan waktu $51 \%$ lebih lama dibanding metode pengiriman file biasa. Hasil uji Coba dapat dilihat pada tabel berikut ini: 
Tabel 6.

Hasil Uji Coba Upload Menggunakan Metode Chunked Upload

\begin{tabular}{|c|c|c|c|}
\hline No & $\begin{array}{l}\text { Waktu Pengiriman } \\
\text { Server (Jam:menit:detik) }\end{array}$ & $\begin{array}{l}\text { Waktu Penerimaan } \\
\text { Server } \\
\text { (Jam:menit:detik) }\end{array}$ & $\begin{array}{l}\text { Waktu } \\
\text { Selisih(detik) }\end{array}$ \\
\hline 1 & $12: 09: 46$ & $12: 10: 14$ & 28 \\
\hline 2 & 12:11:00 & $12: 11: 58$ & 58 \\
\hline 3 & $12: 15: 26$ & $12: 15: 58$ & 32 \\
\hline 4 & $12: 17: 17$ & $12: 17: 47$ & 30 \\
\hline 5 & $12: 18: 37$ & $12: 19: 02$ & 25 \\
\hline 6 & $12: 22: 12$ & $12: 22: 40$ & 28 \\
\hline 7 & $12: 23: 38$ & $12: 24: 38$ & 60 \\
\hline 8 & $12: 25: 30$ & $12: 26: 05$ & 35 \\
\hline 9 & $12: 28: 57$ & $12: 29: 28$ & 31 \\
\hline 10 & $12: 33: 10$ & $12: 33: 41$ & 31 \\
\hline $\begin{array}{l}\text { Rata- } \\
\text { rata }\end{array}$ & & & $=32.8$ \\
\hline
\end{tabular}

Tabel 7.

Hasil Uji Coba Upload Menggunakan Metode Upload PHP

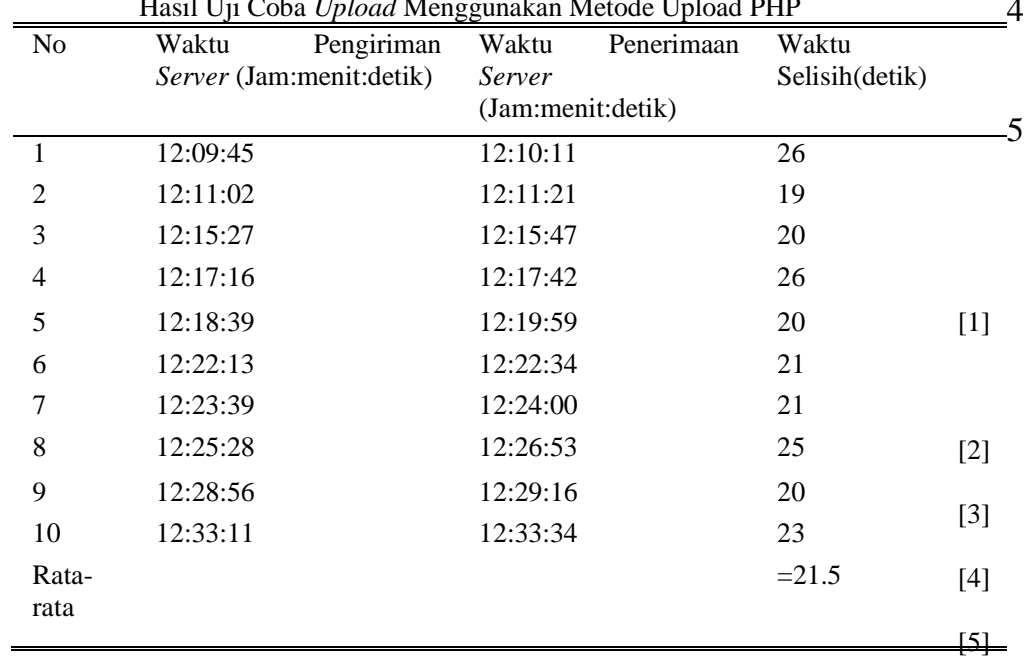

VI. KESIMPULAN

Berdasarkan hasil uji coba yang telah dilakukan, terdapat berapa kesimpulan yang bisa diambil, yaitu:

1. Pemotongan file tugas bersifat adaptif dengan kecepatan pengguna, server dapat menerima file sesuai dengan yang dikirim pengguna

2. Pada uji performa pada keadaan normal tanpa latensi server dapat melakukan proses dengan cepat yaitu sekitar 29 detik,pada kondisi jaringan $3 \mathrm{~g}$ proses terjadi selama 68 detik sedangkan pada kondisi GPRS proses terjadi selama 596 detik.

3. Pada uji performa pengiriman file metode pemotongan, didapatkan bahwa kecepatan pengiriman file metode pemotongan file lebih lambat $51 \%$ dibandingkan dengan metode tanpa pemotongan

4. Waktu yang dibutuhkan metode pemotongan file lebih lama karena terdapat proses penggabungan kembali file yang sudah terkirim pada server

5. Aplikasi dapat melanjutkan pengiriman file apabila jaringan terputus saat proses pengiriman file.

\section{DAFTAR PUSTAKA}

Omniupdate.com, "CMS evaluation guide," omniupdate.com. [Online]. Available: https://omniupdate.com/_resources/pdfs/white_papers/cms_evaluati on_guide.

[2] H. X. dan H. Wenfa, "An Innovative Web-Based Collaborative Learning Model and Application Structure," 2008.

3] R. Z. dan C. Zhang, "A Framework for Collaborative Learning System Based on Knowledge," 2009.

[4] Php.net, "PHP: Hypertext Preprocessor," php.net. [Online]. Available: http://php.net/.

S. Batra, "AJAX - Asynchronous Java Script and XML," 2003. 